\title{
Feature
}

\section{Volcanic particles in agriculture and gardening}

Volcanic pyroclasts of small size, such as lapilli and small pumice stones, are widely used in agriculture, gardening, and for pot plants as natural inorganic mulch. The technique of using pyroclasts to enhance topsoil stems from the eighteenth century, and specifically from the AD 1730-1736 eruption on Lanzarote. Critical observations on plant development during and after the eruption showed that the vegetation died when buried under a thick layer of lapilli, but grew vigorously when covered thinly. While the agriculture of Lanzarote was restricted to cereals before the eruption, it diversified to many kinds of fruit and vegetables afterwards, including the production of the famous Malvasía wines in the Canaries. The population of Lanzarote doubled in the years after the eruption, from about 5000 in 1730 to near 10000 in 1768 , predominantly as a result of the higher agricultural productivity. This outcome led to widespread use of lapilli and pumice fragments throughout the islands and eventually the rest of the globe. Lapilli and pumice provide vesicle space for moisture to be retained longer within the planting soil, which can create an environment for micro-bacteria to thrive in. Through this route, nutrients from volcanic matter are transported into the surrounding soil where they become available to plant life. The detailed processes that operate within the pyroclasts are less well understood, such as the breakdown of nutrients from the rock matrix and transport into the soil by biological action. Further studies promise significant potential to optimize future agricultural efforts, particularly in otherwise arid areas of the globe.

Volcanic eruptions are one of nature's most powerful events, and the consequences are at times devastating for people and livestock in the vicinity of erupting volcanoes. Irrespective of the risks, people have settled on volcanic regions for thousands of years because volcanoes also provide great benefits for creation of stone tools, collection of metals, and especially for agriculture. Volcanic soils, and particularly those of basaltic composition, are high in nutrients and harvests are often more frequent or more abundant nearer to volcanoes than further away. While the short term effects of volcanic eruptions may be devastating, large eruptions may have surprisingly positive long-term effects for mankind and society.
This may be the case for the 1730 to 1736 eruption on Lanzarote in the Canary Islands, which was considered a devastating blow to the local population and its industries at the time, but turned out to provide a lesson of global significance. In this article, we briefly review the 1730-1736 eruption and investigate bubble textures in lapilli from a disused lapilli quarry on Gran Canaria. We detected abundant communities of freshwater microbes in the bubbles, such as diatoms, which emphasize the ability of volcanic lapilli to retain moisture inside the vesicles (i.e. the former bubbles) and maintain a hydrous micro-climate for organisms to thrive in. Additionally, hydrous oxidation may help to break down the rock

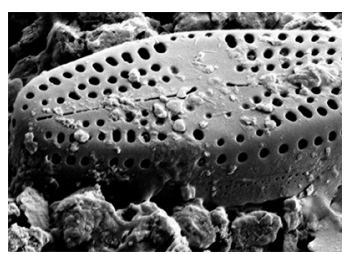

Valentin R. Troll1,2, Juan Carlos Carracedo², Beatrice Jägerup ${ }^{3}$, Michael Streng ${ }^{3}$, Abigail K. Barker ${ }^{1}$, Frances M. Deegan', Francisco PerezTorrado ${ }^{2}$, Alejandro RodriguezGonzalez² \& Harri Geiger $^{1}$

'Department of Earth Sciences, Section for Mineralogy, Petrology \& Tectonics, Uppsala University, Villavägen 16, Uppsala, Sweden valentin.troll@geo.uu.se ${ }^{2}$ Instituto de Estudios Ambientales y Recursos Naturales (i-UNAT), University of Las Palmas de Gran Canaria (ULPGC), 35017 Las Palmas de Gran Canaria, Spain ${ }^{3}$ Department of Earth Sciences, Paleobiology, Uppsala University, Villavägen 16, Uppsala, Sweden 

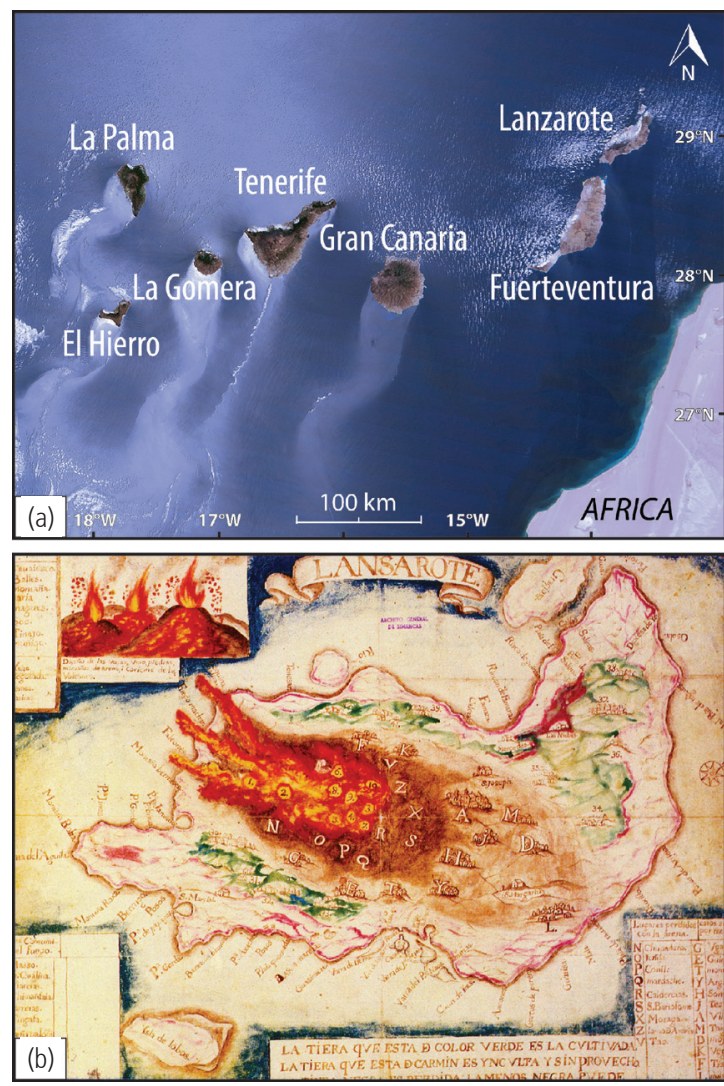

and provide nutrients to the micro-organisms that can then release these nutrients into the surrounding soil or provide them directly to the roots of growing plants.

\section{The Lanzarote $1730-1736$ eruption}

Lanzarote is the easternmost Canary Island and, along with Fuerteventura, forms the oldest part of the Canary Archipelago (Fig. 1a). The Canary Islands represent an intra-plate oceanic volcanic setting located on top of a slow moving (African) plate. The islands rest on thick and rigid (Jurassic) oceanic lithosphere near the passive continental margin of the African continent. Lanzarote has had a long volcanic history reaching back at least $15 \mathrm{Myr}$ but today the island reaches only $671 \mathrm{~m}$ above sea level at its highest point due to millennia of erosion that has outpaced the eruption of new materials on the island. However, despite the eroded and mature landscape of Lanzarote, earthquakes shook the island in mid1730 and an eruption commenced in September 1730 (Fig. 1b). This was to become the longest so far recorded basaltic fissure eruption in the history of the Canaries. When the eruption ended in 1736, it had been going on for a staggering 2056 days and a total of 23 percent of Lanzarote's land area was blanketed with lavas, black lapilli and ash (the latter two being called 'picón' and 'arena' in the Canary Islands), with
Fig. 1. a. Map of the Canary Islands off NW-Africa (image courtesy of NASA). b. Oil painted map of Lanzarote from November 1730 , indicating the extent of lavas and pyroclastic deposits (labelled 'sands') that were emitted up to that point during the ongoing eruption. The sequence of destroyed villages document the shifting vent sites (courtesy of the Archivo General de Simancas, Valladolid). The island was almost completely evacuated in 1731.

Fig. 2. a. Valley of Femes within the Ajaches shield massif, Lanzarote. The U-shaped profile of the valley is the result of filling up a V-shaped ravine with erosional detritus and especially with eruptive lapilli (picón). This is further supplemented with fresh lapilli layers (dark patches), making this area agriculturally viable despite extremely low precipitation. b. View from the West into the valley of La Geria, Lanzarote. Some 10000 funnelshaped holes have been dug into the thick layers of 'picón', and planted with vines. Traditionally, only one vine is used per hollow. The low semicircular walls protect the plants from the constant winds and from drying out. c. Historical postcard (late 1950s), showing the traditional 'La Geria' holes in more detail (courtesy Cabildo Insular de Lanzarote). $\mathbf{d}$. Vine plant of the famous Malvasía grape within one of the holes. Note the roots penetrate into the soil beneath the lapilli layer. a total erupted volume of between 3 and $5 \mathrm{~km}^{3}$. In total, 26 villages were destroyed but there were few casualties as the population was efficiently evacuated in 1731. The eruption was closely watched from the neighbouring islands of Fuerteventura and Gran Canaria, where most of the population found refuge during the eruptive crisis (see Fig. 1). Indeed, the first reaction of the islanders was one of desperation, as they believed that the lapilli had permanently destroyed the island's agricultural farmland. The report sent from Lanzarote to the Royal Court of Justice of the Canary Islands, which was based on Gran Canaria at that time, reports: '... So much fire and "sand" was expelled that all the heart of the island - all the best land in the area-is lost because of the sands...'. At the end of 1731, despairing of never seeing an end to their trials, the villagers left the island.

While the eruption was still young, hopes were strong that it would subside swiftly, and so efforts were made to record and document the unfolding events. In late 1730 the Royal court in Madrid sent Bishop Dávila y Cárdenas to Lanzarote to report on the damage and advise on measures to improve the situation. On arrival on Lanzarote, the Bishop inspected the lava fields and scoria deposits around the numerous vent sites. While walking through the debris, the Bishop noted something unusual. While the lava fields were generally of bad constitution for agriculture and referred to as 'malpaís' ('Badlands' in Spanish), the areas covered with lapilli were highly
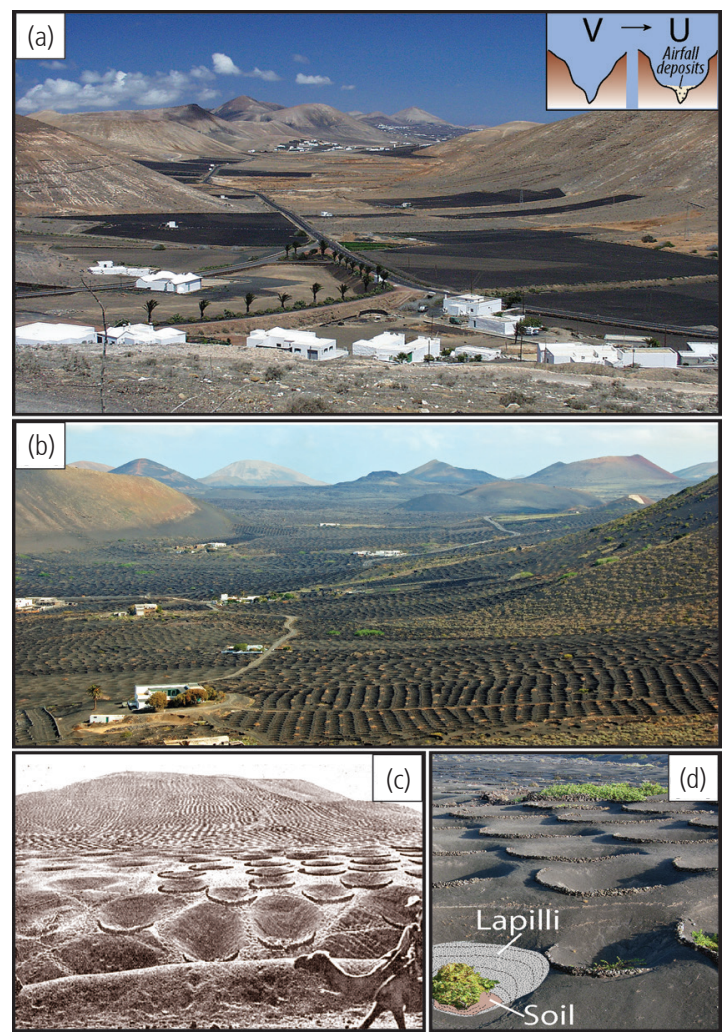
variable. Certain regions were flourishing, while other areas showed no surviving vegetation. This awoke the Bishop's curiosity and he investigated further. He soon noted that the enhanced blooming was constrained to areas with a lapilli cover of only a few centimetres and that a thicker lapilli cover killed off the pre-existing plants. The Bishop concluded that the ejected scoria helped plant growth if applied in moderate doses. When people returned to Lanzarote, they took advantage of this new discovery and began, on the Bishop's advice, to cover their crop fields with the small, vesicular volcanic lapilli that were now abundantly available on the island from the 17301736 eruption.

The result was a resounding success and the fields soon recovered rich harvests of crops in the areas where the 'picón' technique was applied. Following the introduction of this new agricultural method, the population of Lanzarote doubled in the years after the eruption, from about 5000 in 1730 to near 10000 in 1768 , despite the limited arrival of new settlers. As is the case for many of the Canary Islands, Lanzarote's climate is arid, with an average rainfall of only $150 \mathrm{~mm}$ per year, which is similar to that of the Sahara desert. The lapilli cover must have affected the moisture level of the soil profoundly. Indeed, George Glass, in his description of the Canary Islands of 1764 affirmed that 'Lanzarote never produced wine until a volcanic eruption covered many fields with dust and small pumice stones that improved the agricultural land and now there are vineyards on the island that prosper and give good grapes'. Indeed, Lanzarote produces the well-known 'vino malvasía' since that time, a grape originally derived from Greece (named after the district of Malevizi on Crete) which usually prefers a Mediterranean climate. This success story led to the exportation of the mulching technique to the other islands and was soon applied throughout the Spanish empire and the rest of the world.

The main reason for the success of 'picón', at least in a Canary context, is that the air predominantly brought in by the trade winds is usually humid and clouds frequently surround the highlands in the early hours of the day (this 'sea of clouds' phenomenon was first described by A. von Humboldt). When the morning hours give way to the hot midday sun, the moisture from the clouds evaporates swiftly, unless it is trapped within the vesicles of small lapilli and scoria particles. The moisture is then gradually released from the lapilli and less water leaves the soil by evaporation. This gives plants access to a steady supply of water, which explains the blooming effect observed by Bishop Dávila y Cárdenas in 1731.

On Lanzarote, lapilli ejected during the 1730-1736 basaltic eruption came from a number of vent sites. For instance, different layers of lapilli from different eruptive vents accumulated in the valley of La Geria,
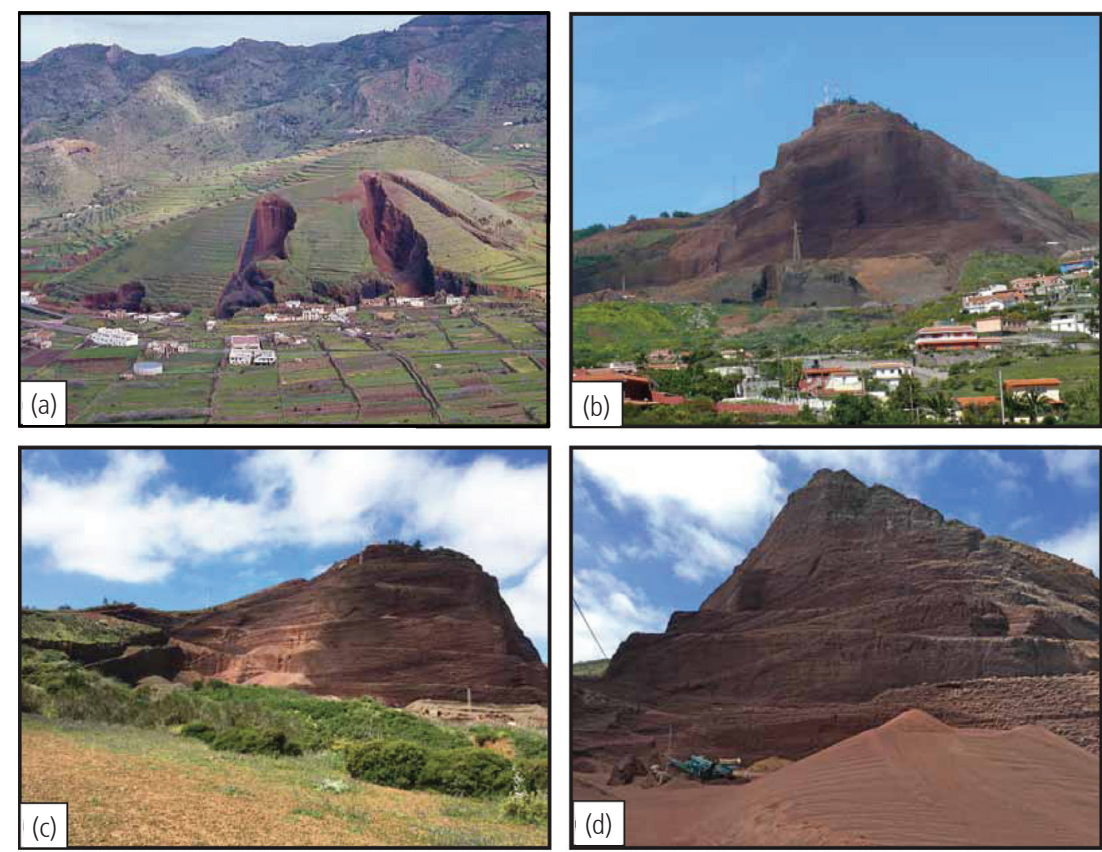
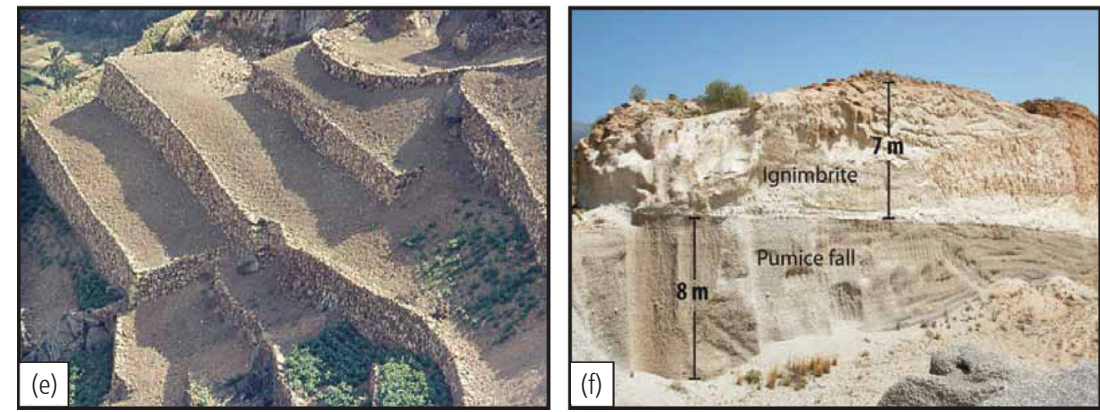

where the pyroclasts are several metres thick (Fig. 2). Cultivation in the Canaries was a difficult mission for early settlers, particularly in the arid central and eastern islands. These conditions changed when the 'picón' mulching method was discovered on Lanzarote and was soon applied on the other islands too. The use of basaltic lapilli and pumice on the fields of Gran Canaria, Tenerife and La Palma enabled the dramatic expansion of the cultivation area and multiplied harvest yields. To cover fields in this manner was in due time called 'enarenado' (mulching), and the technique left its mark throughout the Canary Islands. Lapilli and pumice-covered fields have ever since been a hallmark of the Canary landscape (see Fig. 2).

Indeed, the Canary Islands were the perfect site for developing this inorganic mulching technique due to the numerous recent eruptions and the resulting abundance of suitable volcanic pyroclasts. An unfortunate side-effect after centuries of mining lapilli and pumice is, however, that many of the cinder cones on the islands are now heavily damaged (Fig. 3), and some cinder cones have been completely removed. Cinder cones in the Canaries are in fact an 'endangered species'. For example, Alexander von Humboldt described three prominent cinder
Fig. 3. Lapilli and pumice quarries on Tenerife. a. Mña. de El Palmar, a 153 ka old volcanic cone in NW-Tenerife and (b-d) Montaña Birmagen, in NE Tenerife, which has been extensively quarried for lapilli, to improve farm land and provide aggregates for construction. e. Landscape of agricultural terracing on mountainsides covered with pumice in South Tenerife. f. Chimiche quarry in SE Tenerife where phonolitic pumice from the Plinian 0.6 Ma Granadilla eruption has been sourced. 
cones in the Orotava valley of Tenerife in 1799, but today only two remain, the third has fallen victim to quarrying for agriculture and construction works, while the other two are now topped by buildings. Another notable example is the quarried basaltic cinder cone of El Palmar on Tenerife, which has been divided into slices by quarries with different owners (Fig. 3a). Yet another example is the Chimiche quarry on Tenerife, which carries deep scars from extensive removal of pumice (Fig. 3f). Although not basaltic in composition, the $15 \mathrm{~m}$ thick layer of phonolitic airfall pumice of the 0.6 Ma Granadilla eruption is widely used today on the crop fields of Southern Tenerife, where it helps to grow the 'giant onions' for which southern Tenerife is famed. On Gran Canaria several active picón quarries are in operation (Fig. 4), such as the Mña. Pelada and Santidad quarries, and a series of disused ones exist, such as at Montaña de Las Palmas, Bandama, Arucas, and Lomo del Seminario and of course Montañón Negro, where the samples in Fig. 7 were collected.

\section{Mulching on a large scale}

Nowadays mulching is no longer restricted to the Canary Islands, but has developed into a global industry as a creative way of improving soil quality and thus agricultural production. Today, mulches are divided into two groups; organic and inorganic. Organic mulches consist, for example, of bark chips or straw and are frequently used in public parks to provide soil with an internal composting system. Inorganic mulches, in contrast, are normally rock pieces of different origin or completely man-made materials, such as chopped rubber tires or plastic flakes, with the aim of increasing soil porosity, decreasing water evaporation and soil erosion, and to release nutrients that stimulate environmental conditions for micro-organisms to live in the rock fragments and the resulting soil.

The 'trick' of mulching lies in obtaining the right combination of components between the soil layer and external factors (water, sun). On the Canaries, black lapilli fragments are most frequently used in mulching, and the layers are not thicker than $20 \mathrm{~cm}$. If they are much thicker or thinner, only sub-optimal conditions are achieved. Although we know from the resulting harvests that scoria and pumice both work favourably as a mulching material for increased crop production, the processes that operate to achieve this result are still a subject of discussion, and indeed of intense research. Since precipitation is generally sparse on Lanzarote as well as the other Canary islands, one widespread theory is that the pumice or scoria mulch layer offers a much larger surface area for enhanced condensation from nocturnal precipitation and from the frequent 'sea of clouds' that forms at higher
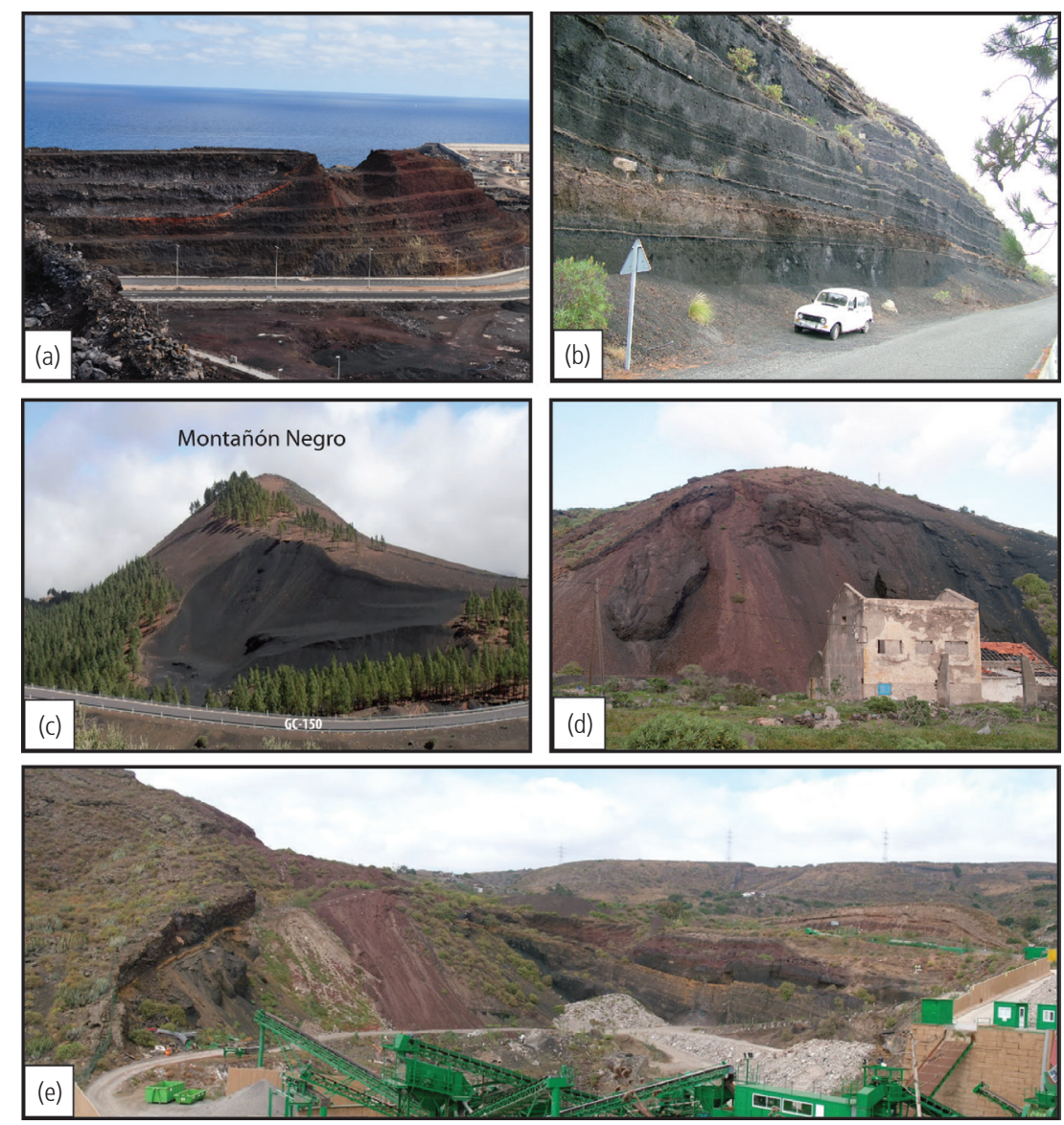

altitude on the islands. In addition to attracting more moisture from condensation, water will also be partly trapped in the vesicles and even exposure to intense sun will not remove all the moisture as water is most likely stored as steam when black scoria particles are exposed to the Canary midday sun for up to several hours a day.

\section{Lapilli and pumice: their origin and appearance}

Lapilli and pumice are typically fragmented lava particles produced from mafic (e.g. basaltic) and silicic (e.g. phonolitic, trachytic) eruptions. Basaltic eruptions are relatively gas-poor and generally show Strombolian to Hawaiian eruptive styles, producing lava fountains and very fluid lava flows. Strombolian eruptions usually produce rhythmic bursts of fluid lava that solidifies during ballistic transport, creating fragments of hardened lava a few $\mathrm{mm}$ to a few decimetres in size, which are collectively called tephra (Figs 5, 6). Lapilli are tephra fragments of a grain size of 2-64 mm, which can be blown hundreds of metres away from the vent and are frequently dispersed by wind up to several kilometres around a vent site. More viscous and gas-rich lavas, such as those derived from silicic magmas (e.g. phonolites and rhyolites),
Fig. 4. Active and abandoned lapilli quarries on Gran Canaria. a. Large former quarry on La Isleta, the volcanic isthmus in the NE of the island. $\mathbf{b}$. Former quarry site on the flank of Pico de Bandama volcano, NE-Gran Canaria. c. Former quarry site at Montañón Negro volcano, central Gran Canaria. d. Partially collapsed former quarry wall at Montaña Negra de Jinámar volcano, E-Gran Canaria. e. Large operating lapilli quarry at Sima de Jinámar volcano, also in E-Gran Canaria (see also Fig. 5). 
Fig 5. Inside active 'picón' quarries on Gran Canaria; a. Montaña Santidad Quarry in NE- Gran Canaria. A large portion of the cinder cone has already been removed. b-f. One of the largest picón quarries on the island is at Montaña Pelada volcano. Lapilli are extracted, sieved and sorted into 'picón-hidropónico', 'picón normal' and 'arena', which are used respectively for gardening, agriculture and as supplement for Portland cement. The main product of the quarry is 'picón normal' for agriculture, which supplies local needs on Gran Canaria and is also exported to some of the other islands.

produce Plinian eruptions, the largest and most violent of all the types of volcanic eruptions. These frequently create eruption columns of ash and gas that can rise up to $50 \mathrm{~km}$ high and are usually shaped like a mushroom when they finally reach neutral buoyancy in the atmosphere and can disperse falls of fine-fragmented pumice and ash many hundreds to thousands of kilometres from the source volcano. In the Canaries, basaltic lapilli abounds on all the islands (Figs 5, 6), while phonolite and trachyte pumice is only present in appreciable quantities on the central islands of Tenerife and Gran Canaria.

\section{The microscopic ecosystem inside lapilli}

To further investigate the microcosmos within basaltic pyroclasts, we sampled scoria from a disused quarry at a Holocene cinder cone on Gran Canaria that is marked by very fresh 'picón' and has produced much of the lapilli cover for the local vineyards in this region of the island. The Mtn. Negro vent complex is about 2900 years old, as dated by Rodriguez-Gonzalez and coworkers in 2009, and scoria as well as frothy xenopumice (lighter coloured pumice-like xenoliths) have been collected from exposed surfaces (see Fig. 4). The light coloured xenoliths are pieces of former sediment and older igneous rocks, as recognized by Hansteen and Troll in 2003, and were brought to the surface by the ascending Montañón Negro magma. During ascent the xenoliths partially melted and frothed up as a result of degassing-induced decompression. In fact, the sedimentary xenoliths share many characteristics with the xeno-pumice found amongst the floating stones of the 2011 El Hierro eruption as discussed by e.g. Troll and coworkers in 2012 and Carracedo and others in 2015. The surrounding basalt that forms the main constituent of the deposits is highly vesicular as well, but the mineralogy is considerably different, comprising larger phenocrysts of olivine and pyroxenes and a high fraction of basaltic glass.

When investigating the vesicles (former bubbles) of these scoria fragments, a variety of micro-organisms were discovered and identified as dominantly diatoms using scanning electron microscopy (SEM) techniques (Fig. 7a-f), possibly of the genera Pinnularia and Luticola. In one sample the scaled tests of the thecamoebian Euglyphia sp. were also likely present. Thecamoebians
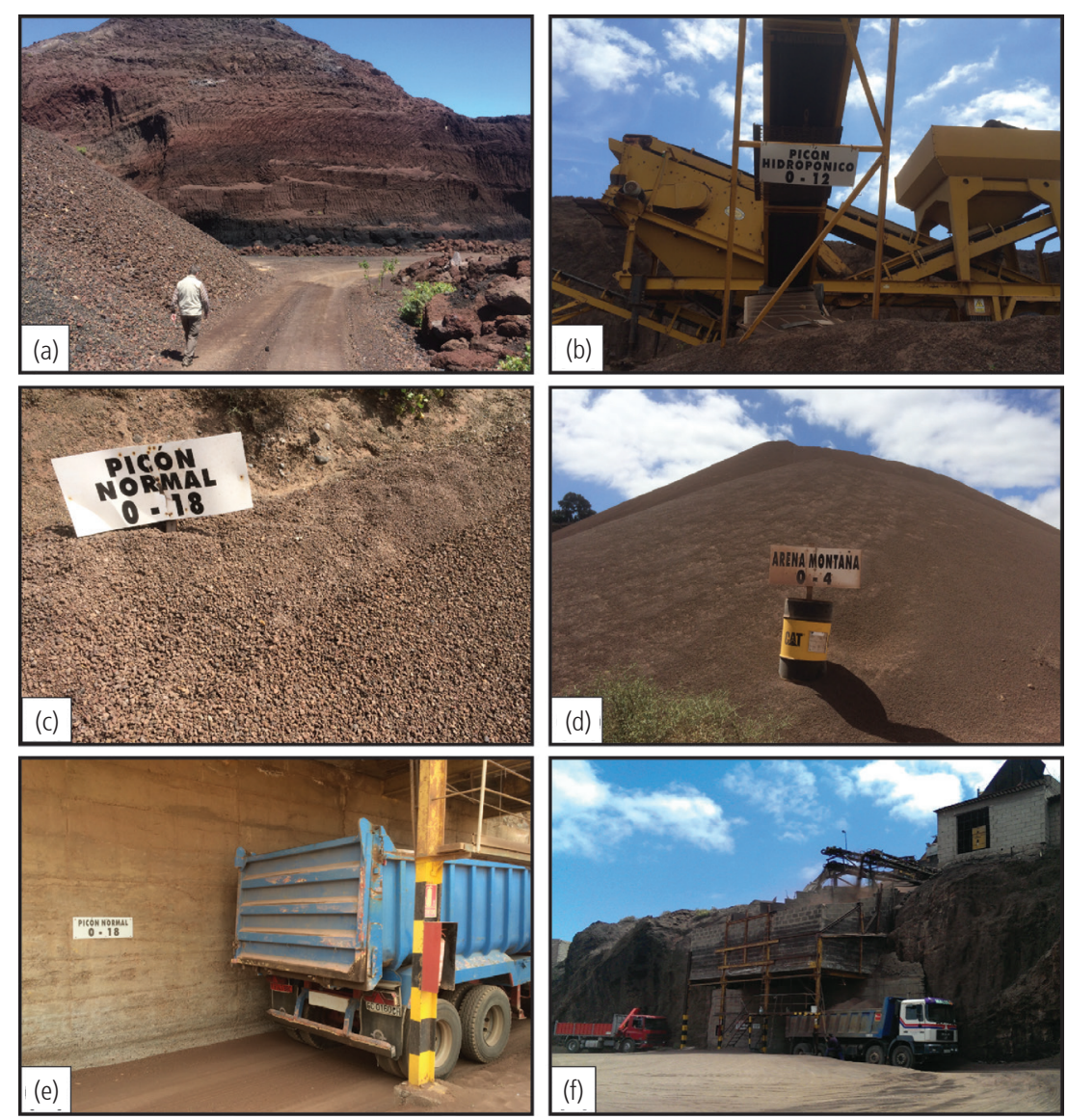

are single-celled organisms globally common in freshwater environments and soil. Judging by SEM images, all of the mentioned organisms seem to have lived within the vesicles of the investigated volcanic fragments (see Fig. 7a,d). Furthermore, all of these organisms are dependent on the supply of freshwater, and so the micro-environment inside the vesicles at Montañon Negro must have contained sufficient moisture to sustain such microbial communities. Notably, fossil thecamoebians of the same family as the discovered Euglyphia sp. were previously described

Fig. 6. a. Teneguía eruption, La Palma, 1971, which produced abundant basaltic lapilli beds during its Strombolian phase. b. Typical lapilli (picón) deposit of loose particles of dominantly lapilli size at Lomo del Seminario quarry in NE Gran Canaria. c. Grapevine on lapilli covered field on the slopes of Mta. Bandama, NE Gran Canaria.
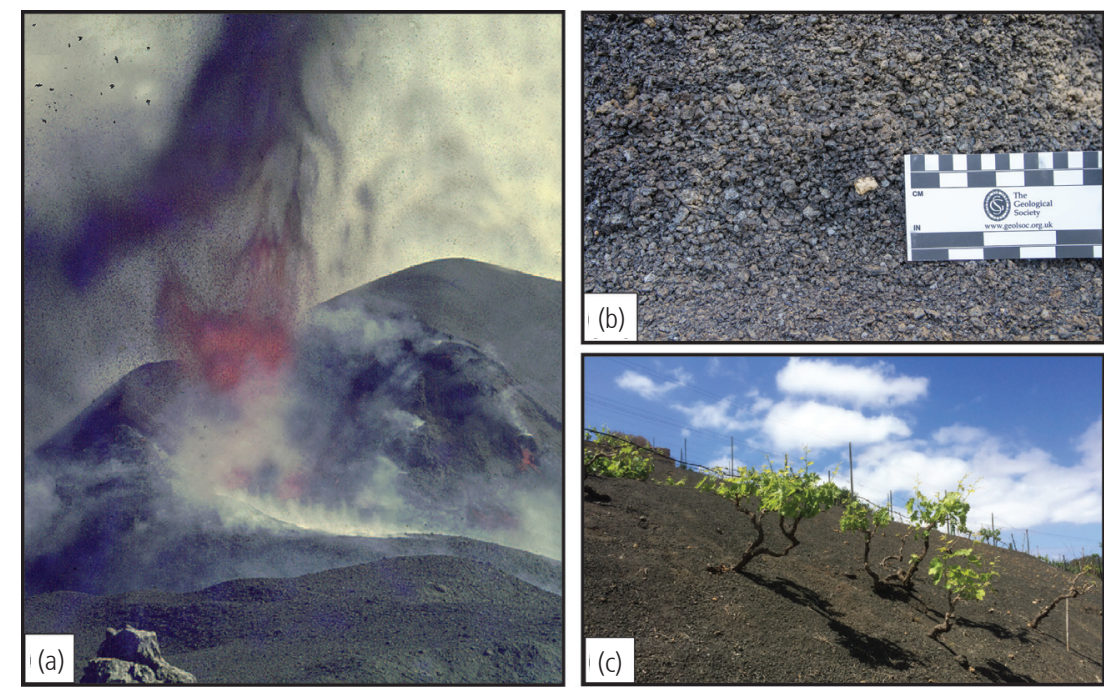

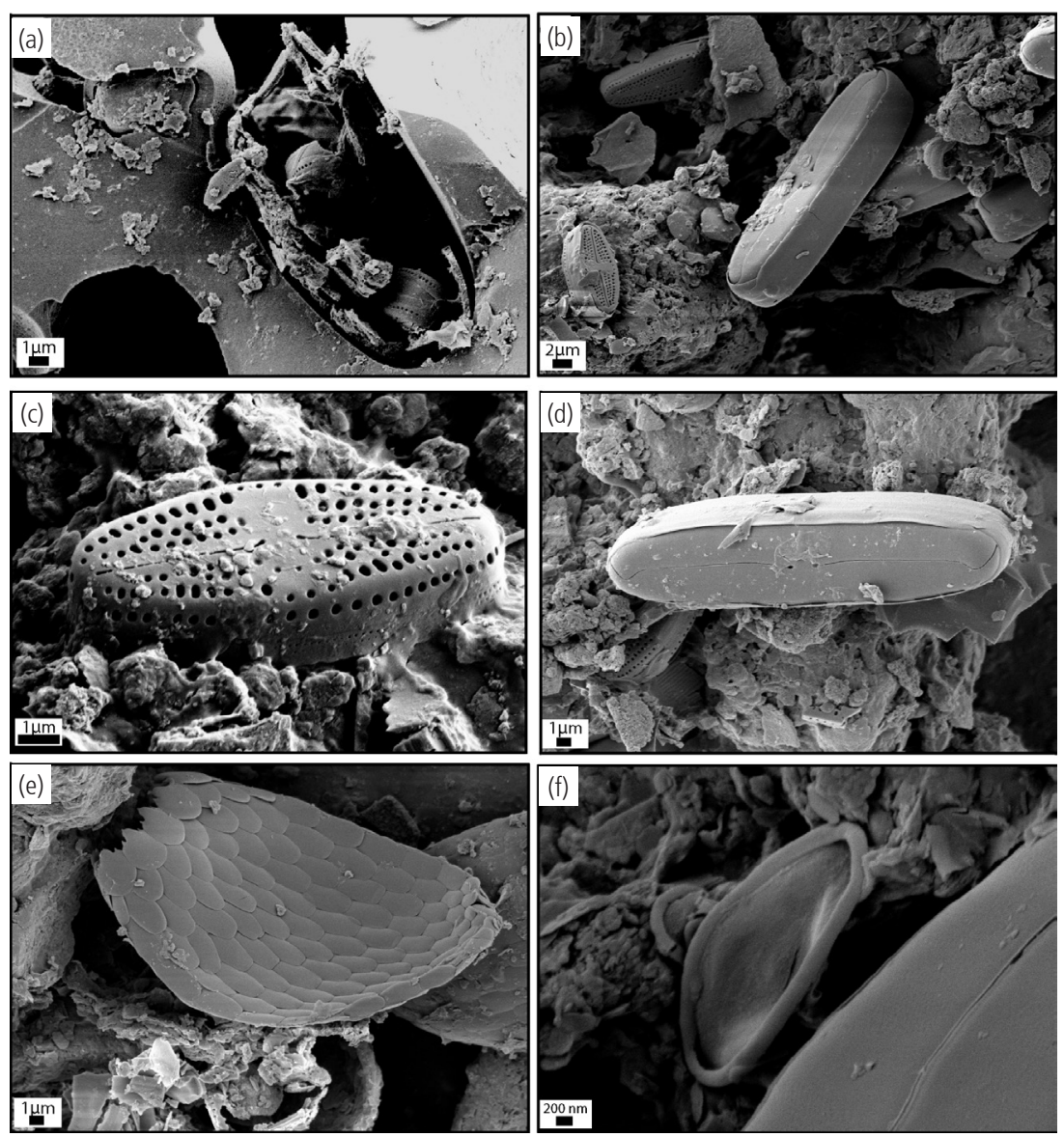

Fig. 7. SEM images of diatoms and other micro-organisms found in vesiculated lapilli from Gran Canaria. a. Several

frustules (= silicate tests

of diatoms) in a vesicle. $\mathbf{b}$.

Frustules of Pinnularia sp. and Luticola sp. next to each other. c. Luticola sp. d. Pinnularia sp. note that the organic casing is still present, obscuring pores and slits of the frustule. e. Test of the thecamoeba Euglyphia $\mathrm{sp}$. with the characteristic denticulate plates around the aperture. $\mathbf{f}$. Remains of an as yet unidentified micro-organism. from Miocene crater-lake deposits in the Eifel alkaline volcanic district in Germany, as noted by Foissner \& Schiller in 2001.

\section{Outlook}

The valuable properties of lapilli-sized 'picón' and pumice have lately been exploited by a series of global corporate companies that mine, produce and sell scoria, pumice and pumice-derived products world-wide, e.g. for concrete supplements, abrasives (e.g. in toothpaste and body scrubs), and to produce 'stone washed' denim jeans, but of course also for improving soil quality in potting and garden soil as well as in larger agricultural efforts. The small, grey to brownish-red grains that supplement the soil in the flower pot on your window sill is likely exactly that: pumice or scoria or artificial granular imitations. If you were to investigate in detail, you would probably find that communities of micro-organisms live in these vesicular particles and help break down the rock material to supplement the soil.

While it is fascinating to wonder what creatures you might find in the flowerpot on your window sill or in your garden soil, it is also appropriate to think back to Bishop Dávila y Cárdenas and his visit to Lanzarote in 1730, which effectively started an agricultural revolution and the targeted use of volcanic materials for agricultural benefits. Many more people can be fed because of the Bishop's foresight, which is likely an aspect we will have to remind ourselves of when visiting some of the badly quarried and decimated vents in the Canaries and elsewhere. These vents have delivered a magical ingredient to 'engineer' soil quality to a degree that crops are grown more effectively, which implies that mulching can help exploit arid regions that are otherwise considered badlands ('malpaís') (Fig. 8), and can help speed up soil formation that would otherwise take many thousand years in such arid conditions. Apart from holding moisture for longer, a further advantage of picón, or its artificial imitations, is the steady supply of nutrients via microorganisms, which contrasts the common artificial soil fertilizers that are usually applied at regular intervals and frequently incur rapid run off with potentially negative consequences for local stream, lake and groundwater. Another benefit is that 'living' soil (i.e. with a high content of micro-organisms) sequesters considerable amounts of carbon from the atmosphere into soil, as is currently discussed by e.g. K. Ohlson, amongst others. Specifically, carbon-dioxide released from the roots of plants to attract and support bacterial action causes soil to become more fertile due to increasing carbon content with time, as $\mathrm{CO}_{2}$ from micro-organisms becomes ultimately locked in soil and is thus at least temporarily removed from the atmosphere.

Mulching has been a beneficial technique in agriculture ever since the 1730-36 eruption on Lanzarote and, because of its simplicity and resounding effect, mulching may become yet more important in the future. In a world with increasing temperatures, changing precipitation patterns, and many depleted groundwater aquifers in arid regions of the globe, it will become increasingly challenging to grow sufficient food to sustain growing populations. This would be helped immensely if we can apply techniques that reduce the need for artificial irrigation. Mulching with picón-type materials may help to keep regions fertile where climate change impacts negatively on crop production and for areas that can be made agriculturally viable by optimizing soil quality. Importantly though, it may, in combination with mild irrigation and the tailored use of additional fertilizers, become a prime component for large industrially run crop farms in currently dry areas of the planet some hundred or thousand years down the line, when feeding a yet more rapidly growing human population might become a very pressing societal concern. 

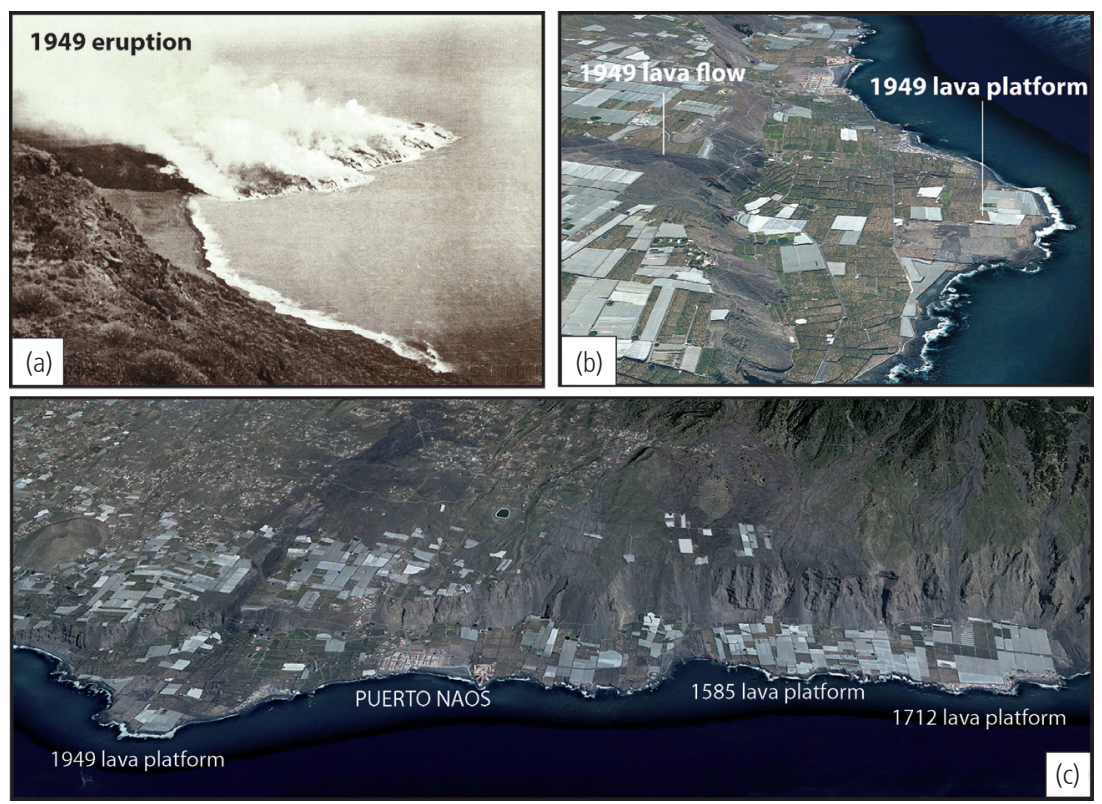

Fig. 8. a. Vintage photograph of the 1949 eruption on La Palma showing the formation of the 1949 lava platform (a lava delta) that formed when the longest flow of the eruption entered the sea at the western shore of the island (image courtesy Cabildo de Insular de La Palma). b. Present Google Earth image of the 1949 lava platform on La Palma with extensive fields and greenhouses for banana, pineapple and tomato cultivation. c. Google Earth image of the Western coast of La Palma, showing the 1949, 1585 and the 1712 lava platforms. These have by now been almost exclusively converted to agricultural land via imported soil and lapilli to create a suitable substrate for agriculture on these flat lava surfaces.

\section{Acknowledgements}

We are grateful to K. Thomaidis for help drafting the figures and to the Swedish Research Council (VR), the Swedish Foundation for International Cooperation in Research and Higher Education (STINT), Uppsala University, and the University of Las Palmas de Gran Canaria for generous financial and logistical support.

\section{Suggestions for further reading}

Carracedo, J.C., Badiola, E.R. \& Soler, V. 1992. The 1730-1736 eruption of Lanzarote: an unusually long, high magnitude fissural basaltic eruption in the recent volcanism of the Canary Islands. Journal of Volcanology and Geothermal Research, v. 53, pp.239-250.

Carracedo, J.C., Day, S.J., Guillou, H., Rodríguez Badiola, E., Canas, J.A. \& Pérez Torrado, F.J. 1998. Hotspot volcanism close to a passive continental margin: the Canary Islands. Geological Magazine, v.135, pp.591-604.

Carracedo, J.C., Singer, B., Jicha, B., Perez-Torrado, F.J. Guillou, H., Badiola, E.R., \& Paris R. 2010. Pre- Holocene age of Humboldt's 1430 eruption of the Orotava valley, Tenerife, Canary Islands.
Geology Today, v.26, pp.101-104.

Carracedo, J., Troll, V., Zaczek, K., Rodriguez-Gonzales, A., Soler, V. \& Deegan, F.M. 2015. The 20112012 submarine eruption off El Hierro, Canary Islands: New lessons in oceanic island growth and volcanic crisis management. Earth-Science Reviews, v.150, pp.168-200.

Foissner, W. \& Schiller, W. 2001. Stable for 15 million years: scanning electron microscope investigation of Miocene euglyphid thecamoebians from Germany, with description of the new genus Scutiglypha. European Journal of Protistology, v.37, pp.167-180.

Lund, J.W.G. 1946. The ecology, size and taxonomy of British soil diatoms. New Phytologist, v.44, pp.196-219.

Glas, G. 1764. The History of the Discovery and Conquest of the Canary Islands with an Inquiry into the Origin of the Ancient Inhabitants to Which is Added a Description of the Canary Islands, Including the Modern History of the Inhabitants, and an Account of Their Manners, Customs, and Trade. Dodsley \& Durham Printing Co., London.

Hansteen, T.H. \& Troll, V.R. 2003. Oxygen isotope composition of xenoliths from the oceanic crust and volcanic edifice beneath Gran Canaria (Canary Islands): consequences for crustal contamination of ascending magmas. Chemical Geology, v.193, pp.181-193.

Ohlson. K. 2016. Dirt First; the farm revolution. Orion, v.35, pp.15-21.

Rodriguez-Gonzalez, A., Fernandez-Turel, J.L., PerezTorrado, F.J., Hansen, A., Aulinas, M., Carracedo, J.C., Gimeno, D., Guillou, H., Paris, R. \& Paterne, M., 2009. The Holocene volcanic history of Gran Canaria island: implications for volcanic hazards. Journal Quaternary Sciences, v.24, pp.697-709.

Troll, V.R., Klügel, A., Longpré, M.-A., Burchardt, S., Deegan, F.M., Carracedo, J.C., Wiesmaier, S., Kueppers, U., Dahren, B., Blythe, L.S., Hansteen, T., Freda, C., Budd, D.A., Jolis, E.M., Jonsson, E., Meade, F., Harris, C., Berg, S., Mancini, L., Polacci, M. \& Pedroza, K. 2012. Floating stones off El Hierro, Canary Islands: xenoliths of preisland sedimentary origin in the early products of the October 2011 eruption. Solid Earth, v.3, pp.97-110. 